\title{
Amyotrophic Lateral Sclerosis Presenting Respiratory Failure as the Sole Initial Manifestation
}

\author{
Fuyuki Tateno $^{a}$ Ryuji Sakakibara ${ }^{a}$ Kengo Kawashima ${ }^{b}$ Masahiko Kishi $^{a}$

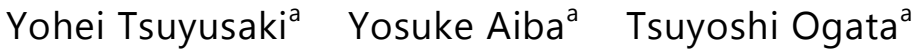 \\ ${ }^{a}$ Neurology, and ${ }^{b}$ Respiratory Diseases, Internal Medicine, Sakura Medical Center, Toho \\ University, Sakura, Japan
}

\section{Key Words}

Amyotrophic lateral sclerosis - Respiratory failure $\cdot$ Chronic obstructive pulmonary disease

\begin{abstract}
It is rare that amyotrophic lateral sclerosis (ALS) presents with respiratory failure as the sole initial manifestation. A 72-year-old man with mild chronic obstructive pulmonary disease developed exertional dyspnea for 13 months. He then progressed to limb weakness that led to the diagnosis of ALS. Although rare, ALS can present with respiratory failure as the sole initial manifestation more than 1 year prior to limb weakness.

(c) 2014 S. Karger AG, Basel
\end{abstract}

\section{Introduction}

Respiratory failure is common in the advanced stages of amyotrophic lateral sclerosis (ALS) and is the major cause of morbidity. In contrast, it is rare that ALS presents with respiratory failure as the sole initial manifestation [1-8]. The majority of patients in previous reports are men, and the interval between respiratory failure and limb weakness is between 0 and 3 months. We here present the case of a male patient with ALS who had respiratory failure 13 months prior to the appearance of limb weakness.

\section{Case Report}

A 72-year-old male gradually developed exertional dyspnea 13 months before his admission to our hospital. He had a history of a lacunar stroke (at the thalamus with mild right

Assoc. Prof. Ryuji Sakakibara, MD, PhD

Neurology, Internal Medicine, Sakura Medical Center, Toho University

564-1 Shimoshizu

Sakura 285-8741 (Japan)

E-Mail sakakibara@sakura.med.toho-u.ac.jp 
Tateno et al.: Amyotrophic Lateral Sclerosis Presenting Respiratory Failure as the Sole Initial Manifestation

leg weakness and numbness without difficulty, which remained unchanged before his admission). He had an occasional cough because of his mild chronic obstructive pulmonary disease (COPD), but he never had dyspnea before. He was first suspected of suffering from heart failure, but his chest X-ray and serum brain natriuretic peptide level were normal. The patient was then suspected to have a worsening of his COPD, and medication for COPD was started in the respiratory disease department, without any benefits. When he was admitted to the neurology department 13 months after symptom onset, he had lost $10 \mathrm{~kg}$. He had no atrophy or fasciculation of the tongue and had no dysarthria or dysphagia but a pre-existing mild right leg weakness. His pinprick sensation had mildly decreased in the right leg. However, on examination, he had a mild fasciculation in his shoulder, the pectoralis major, his arm and his platysma muscles bilaterally. The patient's deep tendon reflexes were exaggerated bilaterally, and his plantar reflexes were extensor. A spirometer showed a normal forced expiratory volume in 1 second of $81.3 \%$ (normal $>71 \%$ ), while he had a markedly low percent vital capacity of $41.3 \%$ (normal $>90 \%$ ). The blood gas analysis (in room air) showed hypercapnia $\left(\mathrm{pO}_{2} 75.8 \mathrm{~mm} \mathrm{Hg}, \mathrm{pCO}_{2} 54.4 \mathrm{~mm} \mathrm{Hg}\right.$ ), and his chest X-ray indicated bilateral phrenic nerve palsy (fig. 1). Electromyography revealed an acute denervation and fibrillation potentials in the diaphragm, tongue, limbs and paraspinal muscles with almost the same severity. A nerve conduction study showed normal results. All laboratory tests were normal. Brain and cervical MRI revealed an old thalamus stroke on his left side. These findings confirmed the diagnosis of ALS. Three days after his admission, he suddenly felt drowsy, and a second blood gas analysis revealed anoxia and $\mathrm{CO}_{2}$ narcosis. $\mathrm{He}$ was placed on artificial ventilation, which improved his consciousness. The patient was started on non-invasive ventilatory support and was discharged from the hospital.

\section{Discussion}

It is rare that ALS presents with respiratory failure as the sole initial manifestation [18]. In such cases, patients often visit pulmonary disease departments first and diagnosing ALS is extremely difficult. In the previous reports, the interval between respiratory failure and limb weakness is between 0 and 3 months (table 1). The only exception is case No. 5 by Chen et al. [8] who presented with limb weakness 12 months after respiratory failure. Our patient's clinical manifestation is similar to that of case No. 5 - he also presented with limb weakness 13 months after respiratory failure.

Clinical features of ALS cases who present with respiratory failure as the sole initial manifestation [1-8], including ours, are unique because (1) all patients, except for one case (by Parhad et al. [3]), are men, with the rate being higher than in the total ALS cohort, (2) motor weakness and atrophy following respiratory failure are present in the limbs, which is in contrast to the observation of bulbar palsy often preceding or occurring together with respiratory failure [9], and (3) preceding pulmonary diseases (COPD, pneumothorax, atelectasis, etc.) occurred in half of the patients - a rate which is higher than that in the total ALS population.

Why respiratory failure becomes the sole initial manifestation in these patients remains uncertain. However, it is reported that denervation by electromyography was more severe in the diaphragm than in any other skeletal muscles [7, 8], and, in these patients, a cell loss of the anterior horn was most severe in the cervical spinal cord along the neuraxis [8]. Therefore, in these patients, phrenic anterior horn cells might have been involved early. The Mechanisms accounting for male preponderance remain unsolved. As for the comorbidity of preceding pulmonary diseases and ALS, experimental studies suggest that comorbid muscle 
weakness [by orthopedic (limbs), pulmonary (diaphragm) etiologies, etc.] might hasten anterior horn neurodegeneration since fast fatigable motor units are more vulnerable to degenerative disease processes in ALS mice [10].

In conclusion, although rare, ALS can present with respiratory failure as the sole initial manifestation more than 1 year prior to limb weakness.

\section{Acknowledgement}

None of the authors received any financial support relevant to this study.

\section{References}

1 Miller RD, Mulder DW, Fowler WS, Olsen AM: Exertional dyspnea: a primary complaint in unusual cases of progressive muscular atrophy and amyotrophic lateral sclerosis. Ann Intern Med 1957;46:119-125.

-2 Fromm GB, Wisdom PJ, Block AJ: Amyotrophic lateral sclerosis presenting with respiratory failure diaphragmatic paralysis and dependence on mechanical ventilation in two patients. Chest 1977;71:612614.

3 Parhad IM, Clark AW, Barron KD, Stauton B: Diaphragmatic paralysis in motor neuron disease. Neurology 1978;28:18-22.

-4 Meyrignac C, Poirier J, Degos JD: Amyotrophic lateral sclerosis presenting with respiratory insufficiency as the primary complaint - clinicopathological study of a case. Eur Neurol 1985;24:115-120.

5 Al-Shaikh B, Kinnear W, Higenbottam TW, Smith HS, Shneerson JM, Wilkinson I: Motor neuron disease presenting as respiratory failure. Br Med J 1986;292:1325-1326.

-6 Carre PC, Didier AP, Tiberge YM, Arbus LJ, Leophonte PJ: Amyotrophic lateral sclerosis presenting with sleep hypopnea syndrome. Chest 1988;93:1309-1312.

7 de Carvalho M, Matias T, Coelho F, Evangelista T, Pinto A, Luís ML: Motor neuron disease presenting with respiratory failure. J Neurol Sci 1996;139(suppl):117-122.

8 Chen R, Grand'Maison F, Strong MJ, Ramsay DA, Bolton CF: Motor neuron disease presenting as acute respiratory failure: a clinical and pathological study. J Neurol Neurosurg Psychiatry 1996;60:455-458.

-9 Pinto S, Pinto A, de Caravalho M: Do bulbar-onset amyotrophic lateral sclerosis patients have an earlier respiratory involvement than spinal onset amyotrophic lateral sclerosis patients? Eura Medicophys 2007;43:4505-4509.

10 Saxena S, Cabuy E, Caroni P: A role for motoneuron subtype-selective ER stress in disease manifestations of FALS mice. Nat Neurosci 2009;12:627-636. 
Tateno et al.: Amyotrophic Lateral Sclerosis Presenting Respiratory Failure as the Sole Initial Manifestation

Table 1. ALS presenting respiratory failure as the sole initial feature

\begin{tabular}{|c|c|c|c|c|c|c|c|c|c|c|}
\hline Year & Author & Patient & $\begin{array}{l}\text { Age at } \\
\text { onset, } \\
\text { years }\end{array}$ & Sex & $\begin{array}{l}\text { Comorbid } \\
\text { disease }\end{array}$ & Respiratory failure & $\begin{array}{l}\text { Internal between } \\
\text { respiratory failure } \\
\text { and limb weakness, } \\
\text { months }\end{array}$ & $\begin{array}{l}\text { Type of limb } \\
\text { weakness }\end{array}$ & Diagnosis & Management \\
\hline 1957 & Miller [1] & case 2 & 71 & M & & exertional dyspnea & $\begin{array}{l}\text { 9? with } \\
\text { weight loss }\end{array}$ & distal limb weakness & ALS, bedside & \\
\hline \multirow[t]{2}{*}{1977} & \multirow[t]{2}{*}{ Fromm [2] } & case 1 & 68 & M & & acute respiratory failure & 2 & distal limb weakness & ALS, pathology & \multirow{2}{*}{$\begin{array}{l}\text { mechanical } \\
\text { ventilation } \\
\text { mechanical } \\
\text { ventilation }\end{array}$} \\
\hline & & case 2 & 69 & M & COPD & acute respiratory failure & 0 & distal limb weakness & ALS, pathology & \\
\hline 1978 & Parhad [3] & case 2 & 46 & $\mathrm{~F}$ & COPD & acute respiratory failure & $1-2 ?$ & distal limb weakness & ALS, bedside & $\begin{array}{l}\text { mechanical } \\
\text { ventilation }\end{array}$ \\
\hline 1985 & $\begin{array}{l}\text { Meyrignac } \\
{[4]}\end{array}$ & 1 & 59 & M & & $\begin{array}{l}\text { Exertional, then acute } \\
\text { respiratory failure }\end{array}$ & $3 ?$ & distal limb weakness & ALS, pathology & $\begin{array}{l}\text { mechanical } \\
\text { ventilation }\end{array}$ \\
\hline 1986 & $\begin{array}{l}\text { Al-Shaikh } \\
\text { [5] }\end{array}$ & 1 & 65 & M & $\begin{array}{l}\text { pneumo- } \\
\text { thorax }\end{array}$ & $\begin{array}{l}\text { sleep apnea, then acute } \\
\text { respiratory failure }\end{array}$ & 2 & $\begin{array}{l}\text { tongue and distal limb } \\
\text { weakness }\end{array}$ & ALS, EMG & $\begin{array}{l}\text { mechanical } \\
\text { ventilation }\end{array}$ \\
\hline 1988 & Carre [6] & 1 & 67 & M & obesity & sleep apnea & 3 & distal limb weakness & ALS, EMG & $\begin{array}{l}\text { tracheostomy, } \\
\text { nocturnal ventilatory } \\
\text { support }\end{array}$ \\
\hline 1996 & $\begin{array}{l}\text { de Carvalho } \\
\text { [7] }\end{array}$ & case 1 & 51 & M & & exertional dyspnea & 1 & distal limb weakness & ALS, EMG & $\begin{array}{l}\text { mechanical } \\
\text { ventilation }\end{array}$ \\
\hline \multirow[t]{3}{*}{1996} & \multirow[t]{3}{*}{ Chen [8] } & & 69 & M & $\begin{array}{l}\text { atelec- } \\
\text { tasis }\end{array}$ & exertional dyspnea & 0 & distal limb weakness & ALS, pathology & \multirow{3}{*}{$\begin{array}{l}\text { mechanical } \\
\text { ventilation } \\
\text { mechanical } \\
\text { ventilation } \\
\text { mechanical } \\
\text { ventilation }\end{array}$} \\
\hline & & case 5 & 68 & M & & exertional dyspnea & 12 & distal limb weakness & ALS, EMG & \\
\hline & & case 7 & 72 & M & & exertional dyspnea & 2 & distal limb weakness & ALS, pathology & \\
\hline 2014 & $\begin{array}{l}\text { present } \\
\text { case }\end{array}$ & 1 & 72 & M & COPD & exertional dyspnea & 13 & distal limb weakness & ALS, EMG & $\begin{array}{l}\text { mechanical } \\
\text { ventilation }\end{array}$ \\
\hline
\end{tabular}
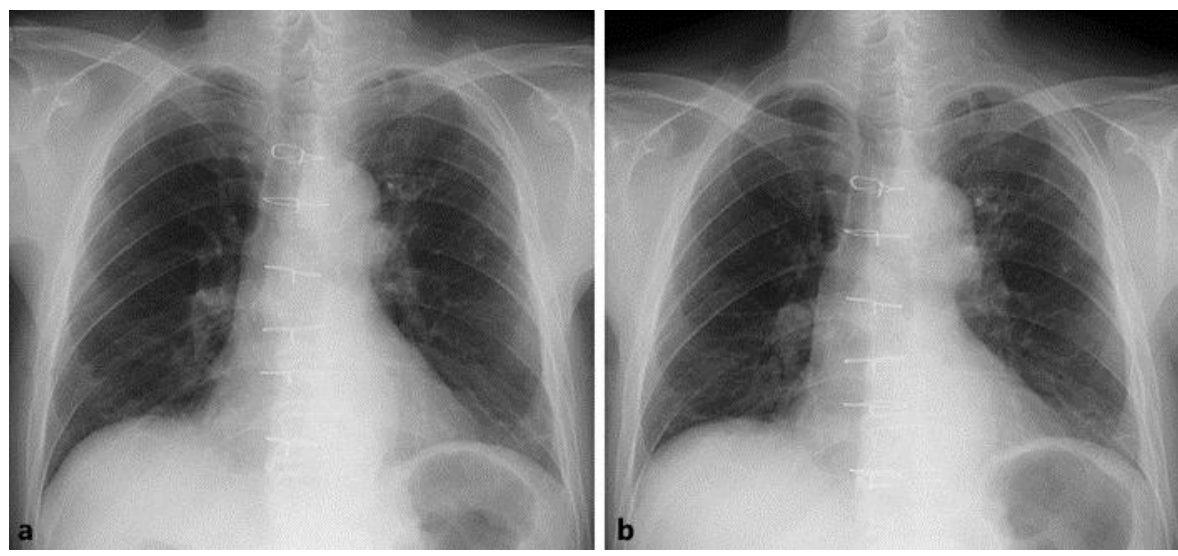

Fig. 1. Plain chest X-rays of the patient. a Deep inspiration. $\mathbf{b}$ Expiration. His chest X-ray showed almost no movement of the diaphragm at deep inspiration and expiration, indicating bilateral phrenic nerve palsy. 